\title{
A Survey on the Role of System Dynamics Methodology on Fossil Fuel Resources Analysis
}

\author{
Behdad Kiani \\ Green Research Center, Iran University of Science and Technology (IUST) \\ Narmak, Tehran, Iran \\ Tel: 98-912-695-4386Ｅ-mail: Kiyani@iust.ac.ir \\ Saeed Mirzamohammadi \\ Department of Industrial Engineering, Iran University of Science and Technology (IUST) \\ Narmak, Tehran, Iran \\ Tel: 98-21-7724-0303 E-mail: mirzamohammadi@iust.ac.ir \\ Seyed Hossein Hosseini (Corresponding author) \\ Department of Industrial Engineering, Iran University of Science and Technology (IUST) \\ Narmak, Tehran, Iran \\ Tel: 98-912-600-2275 E-mail: hoseini@ind.iust.ac.ir
}

\begin{abstract}
In today's world, fossil fuel resources are still the main source for energy supply. Many attempts have been done in order to develop alternative sources of energy, since fossil fuel resources are limited and will be depleted soon or late. Despite these efforts, as international energy organizations declare, fossil fuel resources have the largest share in the world's energy supply. Therefore, the study of exploration, production, and exploitation dynamics of these resources, has been considered a significant topic for many researchers. System dynamics, which is an appropriate method for dynamic studies and policy analysis, has been used as one of the most impressive methodologies in systemic research and application in this area. Besides the illustration of the role of system dynamics in fossil fuel resources analysis, this paper reviews the pioneering system dynamics models in this field. The results of this work would be helpful for researchers who are interested in the dynamic studies of fossil fuel resources' systems.
\end{abstract}

Keywords: Fossil fuel resources, Systems dynamics modeling, Policy analysis

\section{Introduction}

The overall economic growth of every country highly depends on its usage of renewable and nonrenewable energies; Energy is the lifeblood of modern industrial economies. For the last century, world economic growth has been largely affected by the supply of fossil fuel resources production and vice versa.

As the main basis for development, energy sector plays a fundamental role in socio-economic sectors of countries. Energy is one of the most important production factors, and has a remarkable effect on the increase of industrial production level. As it could be seen from figure 1, there is a significant and meaningful relationship between energy consumption and economic development; that is, energy is significant in explaining GDP, and restrictions in energy supply might affect the economic growth (Stern, 1993\& 2000; Hondroyiannis, Lolos and Papapetrou, 2002; Ghali and El-Sakka, 2004; Oh and Lee, 2004; Paula and Bhattacharya, 2004; Lee, 2005; Lee and Chang, 2005 \& 2008; Narayan and Smyth, 2008).

\section{((((Insert Figure1 Here))))}

The use of fossil fuel resources will be the prevailing way for the energy supply for the time being. Based on annual surveys performed by energy-related companies, fossil fuels as fossil fuel resources will remain the dominant source of energy supply to 2030 (World Energy Outlook, 2006; World Oil Outlook, 2008).

All in all, the study of fossil fuel resources' systems is important, especially for economies open to the world markets. Based on diverse methodologies, many energy models have been developed. The mutual relationship between natural energy sector and economy, environment, politics, society, etc has been considered as a challenging issue in these researches. Jebaraj and Iniyan (2006) classified the energy-related models in the literature as follows:

- $\quad$ Energy planning; 
- $\quad$ Energy supply-demand;

- $\quad$ Forecasting (Commercial energy, renewable energy);

- Optimization;

- $\quad$ Energy models based on neural networks and fuzzy theory; and

- Emission reduction

There are almost some system dynamics models in each group. Meanwhile, authors hold this view that the energy-related system dynamics models should be taken more into consideration because of the characteristics of energy systems especially in policy making.

Because of existing characteristics such as considerable delays in industry and new energy development, advanced and fast growing technology, resource limitations and depletions, price fluctuations, increasing costs, growing demand, pollution and environmental concerns, political issues, etc , energy sector has one of the most complicated systems in the world and should be seen holistically (McIntyre and Pradhan, 2003). Hence, decision makers must use transparent, holistic and practical tools to gain better understanding of these systems. They should analyze long term issues and examine various and possible assumptions and scenarios, and subsequently, adopt some effective policies and strategies. They should also be aware of what happens before implementing their programs since their actions are momentous, and the consequences might be costly and irrecoverable.

As a powerful methodology and computer-aided simulation modeling technique, system dynamics has the ability to take feedback loops, delays, effective factors, and their interactions into consideration and mix them deliberately with on hand experiences and data about the system.

It can, therefore, play an effective role in the analysis of energy-related issues. This paper is an effort to clarify this role, by reviewing the most important system dynamics models in this area.

The following section will introduce the system dynamics methodology and its role in fossil fuel resources studies. Main system dynamics models in this field will be reviewed concisely in section 3. Moreover, the key aspects of these models will be discussed in further details. Section 4 concludes the report, with suggestion for further study.

\section{System dynamics and fossil fuel resources modeling}

\subsection{System dynamics (Note 1)}

As one of the first responses to the shortcomings of Operation Research (OR) and other management science techniques for complex problems such as those having large number of variables and nonlinearities, an idea, which now is known as system dynamics, was introduced by J.W Forrester in the 1960s at the Massachusetts Institute of Technology (MIT) (Forrester, 1961). Based on models and tools which were used by control engineers in order to analyze the stability of mechanical and electrical control systems, he developed powerful methods and a set of tools, which were first suggested by Tustin (1953), to model and analyze problems in complex systems.

Successful approaches to learning about complex dynamic systems require (1) tools to elicit and represent the mental models we hold about the nature of difficult problems; (2) formal models and simulation methods to test and improve our mental models, design new policies, and practice new skills; and (3) methods to sharpen scientific reasoning skills, improve group processes, and overcome defensive routines for individuals and teams (Sterman, 2000). System dynamics prides itself on providing practitioners with all of these requirements.

System dynamics is a powerful method to gain useful insight into situations of dynamic complexity and policy resistance. Five steps of modeling process in system dynamics are as follows (Sterman, 2000):

1) Problem articulation (boundary selection): in this step problem, key variables, and time horizon, should be defined; moreover, the historical behavior and the most likely behavior of key concepts in the future should be studied.

2) Formulation of dynamic hypothesis: in this step current theories of the problematic behavior is considered at first; then, a dynamic hypothesis should be developed endogenously. Finally, maps of causal structure should be developed.

3) Formulation of simulation model: the decision rules, parameters, initial conditions and etc should be determined consistently.

4) Testing: there are some serious tests which should be done to assure that the model works correctly and effectively. 
5) Policy design and evaluation: finally, changes in environmental conditions (scenarios), policy options and their interactions, and sensitivity of policies under different scenarios should be examined.

System dynamics is suitable be used to design successful policies in companies and public policy settings. It can be applied to any dynamic system, with any time and scale. In the world of business and public policy, system dynamics has been applied to industries from aircraft to zinc and issues from AIDS to welfare reform (Sterman, 2000). System dynamics society states the span of applications as follows:

- Corporate planning and policy design

- Public management and policy

- Energy and the environment

- Theory development in the natural and social sciences

- Dynamic decision making

- Complex nonlinear dynamics

- $\quad$ Biological and medical modeling

There has been a conscientious fondness to study the dynamics of natural energy systems as an exact complex system because of important feedbacks, nonlinearities, significant delays, etc. These works studied different aspects of system, including exploration, production, investment, technology, demand, substitution, import and export, financial, and so on.

\subsection{The dynamics of energy sector and contribution of system dynamics}

Because of political, economic, environmental, and social factors, energy sector is one of the most complex systems in the world. Regarding increasing economic activities as extremely energy intensive efforts, energy demand is growing day by day. In the case of energy shortage, its price would go up. On the other hand, the increase of energy price with a constant purchasing power might result in the decrease of energy purchase and finally it restricts economic activities. This restriction causes a decrease in demand, and consequently, it would push down the prices.

On the other side, an increase in energy demand would result in the production increase which causes resource depletion because fossil fuel resources are limited and the excessive production will deplete the resources. Resource depletion results in the increase of production costs. Therefore, energy prices would increase. In addition, resource depletion results in the decrease of investment return and the decrease of investment would result in reduction of energy sector's strength. The returns of investments can lead the whole system to be more active in exploration and production activities as well as technology progresses.

Furthermore, the progress of technology to be used in energy sector has a remarkable effect; that is technology development could make noneconomic exploitations profitable.

The existence of substitutes for energy carriers is another effective factor; in other words, price increases could bring on the substitution of other energy resources. The above mentioned dynamic relations of energy sector are shown in figure 2 .

\section{((((Insert Figure2 Here))))}

Energy sector has a distinguished role in energy exporting economies; that is, not only the industrial sector is directly influenced by the performance of this sector, but also since oil exports has a large contribution in national incomes, fluctuations in the sector's performance might gravely influence governments' financial power in domestic and external payments. Therefore, the energy sector plays a crucial role in economic growth of oil exporting countries.

For those countries which are dependent on imports of energy to meet their demand, the dynamics of international energy markets are more pivotal and influencing. Any change in the market, if not foresighted, might have irrecoverable effects on their economy.

All above mentioned was a concise review of dynamics and complexities of fossil fuel resources sector. Analyzing, policy planning, and decision making in this sector is such a consequential concern that governments spend a big deal of money on it. Studying such a multifaceted system requires a comprehensive research tool without which conducting a thorough analysis is impossible.

As a useful research tool, system dynamics is a methodology which takes available expertise as well as system's data and information, and with the help of computer's analytic power and simulation, it makes a single, 
integrated framework. The framework presents and visualizes the results of different assumptions, scenarios, and policy options. The resulted system dynamics model helps decision makers to design reasonable policies and offer options to mitigate possible negative effects.

The next section will try to clarify the role of system dynamics modeling in fossil fuel resources analysis through a concise review of main models in this field.

\section{The review of main system dynamics models of fossil fuel resources}

In this section the most important system dynamics models in the field of fossil fuel resources are reviewed and explained. More details on models, which directly deal with the exploration and production of fossil fuel resources, are shown in Table1. Moreover, Table1 summarizes some strengths and weaknesses of these models.

The first attempts in the field of energy system dynamics modeling were initiated in the early 1970s at MIT in the System Dynamics Group by WORLD models. These models tried to explain "predicaments of mankind"; that is, the increasing demand on the usage of earth's resources and its "limited sinks" for the disposal of pollutants owing to the exponential growth of the World's population may result in global crisis in the future. World models showed how long-term socio-economic interactions would result in the exponential growth of world's population and industrial output. Finally, the increasing exploitation of finite natural resources might bring on the overshoot and collapse behavior in the world's socio-economic systems (Forrester, 1970; Meadows et al., 1972).

The first serious attempt in fossil fuel resources system dynamics modeling was conducted by Roger F. Naill (Naill, 1973). Naill's model was built upon the idea of M. King Hubbert, an American geologist, who believed that natural resources are finite and the production of them appears to have gradual increase to a maximum output, then a long plateau and finally a slow decrease. This behavior forms a bell-shaped curve which is called Hubbert Curve. In this way, Hubbert successfully predicted the peak of oil production for the lower 48 states of U.S. between 1965 and 1970 (Hubbert, 1956; Hubbert, 1982).

As one of the most impressive bases for later model building in this field, Naill's model tried to depict the factors controlling the discovery life cycle of a finite resource. He indicated in his case of U.S. natural gas the normal behavior mode of the system is an initial period of exponential growth in consumption; a period of rising prices where growth in consumption is halted; and finally, a decline in consumption. He found that U.S. natural gas system would have a production peak in 1973 and the decreasing production rate would continue well below the US natural gas discovery rate, between the last 20th century and the early 21 st century where the domestic production rate would come to a stop. He also mentioned that the exact timing of the peak was determined by many factors, including, the growth rate of potential usage, the initial level of unproven reserves, the cost of exploration, and the occurrence of various policies such as subsidies or ceiling price regulations.

After his natural gas model, Roger F. Naill tried to develop a national energy model in order to response to this question that whether the economic growth of U.S. is influenced by energy limitations like those limits to growth which were mentioned in WORLD models. In his model, called COAL, all major US energy sources including oil, gas, coal, and electricity (produced by oil and gas, coal, nuclear, and solar energy) were included; moreover, energy demand was modeled (Naill, 1976). The model seeks the policy combinations which insure the smooth transition from finite domestic fuel sources (coal, nuclear, oil, and gas) to ultimate sources (fusion and solar). It estimates the annual demand for energy, the generation of electricity, and the production of coal. Furthermore, it determines the import requirements of oil and gas, and considers the economics of synthetic oil and gas production from coal. This model was named COAL since it found coal as the best fuel for the US to rely on during the energy transition which was the transition of the US economy from the dependence on domestic oil and gas to alternative energy sources (Radzicki and Taylor, 1997).

The improved and extended version of COAL model, called FOSSIL, was used to analyze and design US energy policy. The model effectively simulated the interactions between energy prices, financial markets, resource depletion, government regulation, changing technologies, and customer behavior which determine future patterns of energy production and consumption. The structure of FOSSIL is similar to COAL; Although, in this model energy sources were expanded to include oil shale, fusion, hydropower, and geothermal in addition to crude oil, natural gas, coal, nuclear, and solar energy. The model simulates the whole process in which a resource is transformed and finally is delivered to satisfy the end-user's demands. During the late 1970s to the early 1990s, the modified version of FOSSIL was used to create and evaluate national energy plans in US department of energy (Budzik and Naill, 1976; FOSSIL2: Energy Policy Model Documentation, 1980).

After extensive improvements in FOSSIL's transportation and electric utilities sectors, the model's name turned 
into IDEAS which stands for Integrated Dynamic Energy Analysis Simulation (Radzicki and Taylor, 1997). IDEAS is a dynamic long-term policy simulation model of the US energy supply and demand which was used as a tool for the integrated analysis of energy-related options. IDEAS provides detailed projections of US energy supply, demand, prices, cost and emissions for up to 40 years (Naill et al., 1991).

John D. Sterman (1980) worked on the feedbacks and interactions between energy sector and the US economy in his $\mathrm{PhD}$ dissertation. He endogenously modeled the influencing energy-economy interactions, which previously was considered exogenous or was not seen.

After Sterman, Thomas S. Fiddaman (1997), based on the last system dynamics energy models in the US, built a climate-economy model called FREE (Feedback-Rich Energy Economy model) which not only explicitly included the dynamics of oil and gas depletion as a source constraint on the energy-economy system, but also it took the dynamics of a "sink constraint like climate change" into account.

The last system dynamics model in the field of energy resources in the US is the Threshold 21 which is the result of the rigorous system dynamics modeling attempts in the US till now. It incorporates society, economy, environment and their interconnections with energy. The model is used to understand energy issues and to show how those issues relate to and impact society, the economy, and the environment. As a quantitative tool for integrated, comprehensive national planning, it supports the overall process of strategic planning by facilitating information collection and organization, in addition to analyzing the results of alternative strategies (Bassi, 2006).

After Naill's model of the US natural gas which was the first serious system dynamics model in the natural energy resource modeling, Sterman in collaboration with George P. Richardson and Pal I. Davidsen, inspired from Naill's model, tried to create system dynamics models of oil industry in the world as well as the US. At first, their question was about finding the accurate method of forecasting the world's ultimately recoverable supply of oil. To find the accurate forecasting method, they created a system dynamics model and compared Hubbert life cycle and USGS geologic analogy method in simulation results. To do so, they used a synthetic data experiment and found that Hubbert's method was clearly the most accurate (Sterman and Richardson, 1985).

Afterward, the model was used to evaluate the amount of ultimately recoverable oil in US (Sterman, Richardson and Davidsen, 1988). Finally, Davidsen, Sterman, and Richardson (1990) developed a model which endogenously generated the complete life cycle of the petroleum resource in the US. The only two major exogenous variables in the model are GNP and the international petroleum prices. The model considered the interactions between several disciplines, including geology, technology, and economics; moreover, it integrated exploration, production, pricing, demand, imports, and the development of substitutes. The model was used to show how the interaction between technological progress, depletion, imports, and the development of substitutes creates the life cycle by altering the dominance of the feedback process in the system.

Bodger, Hayes, and Baines (1989) developed a system dynamics model to study the dynamics of primary energy substitution in the world. This model considered world market penetrations of different primary energy sector over time, and it generated inter-substitution of one energy form for another; accordingly, the model used to evaluate the different future energy options. The model used with the same purpose in New Zealand in 1992 (Bodger, May, 1992); it forecasted the market share of different energy carriers in New Zealand with the passage of the time. The study provided policy makers with appropriate insights to accord national policies especially investments with energy sources' trends.

Choucri, Heye, and Lynch (1992) conducted a detailed simulation analysis to study Egypt's oil industry as a near-typical, non-OPEC, oil-producing developing country. This model was used to explore implications of alternative scenarios for government policies (which affect Egypt's domestic consumptions directly), world oil prices (which influence earnings from export), and geological parameters (which affect the condition of resources and reserves) on patterns of production, exports, and earnings. The model effectively distinguished foreign oil companies and government agents as well as oil-producing regions which disaggregated geologically, to represent the characteristics of oil production; moreover, it made a distinction between domestic consumptions and exports as well as the domestic and international prices. The model had three exogenous variables including export and subsidized domestic prices, discovery and development prices, and initial levels of reserves and undiscovered oil.

Chowdhury and Sahu (1992) developed a system dynamics model in order to study the long-term dynamic behavior of the Indian oil and gas (as finite and nonrenewable fossil fuel resources) exploration/exploitation industry. In compare with other system dynamics models in this field, they considered financial aspects deeply; that is, the model consisted of two sections, including technical and financial sections. The first section 
investigates the exploration and exploitation processes of oil and gas reserves, and the financial section generates the likely future financial statements, namely, the income statement, balance sheet, and fund-flow statement for different activity levels. They studied interactions between important variables to choose alternative policies; moreover, the model could aid decision making by allocating limited financial resources in a satisfactory manner.

Chi, Nuttall, and Reiner (2009), based on Naill $(1973$; 1977) and Sterman and Richardson (1985), developed a system dynamics model of Natural gas system in UK to investigate the main effective factors on the long-term supply and demand and study the nature of the system's behavior; furthermore, the effect of different policies about the growing of import-dependence on unstable exports in the next decades were studied. Finally, they found that supply-side policies alone cannot effectively postpone the peaks in discovery, production, and consumption; Also, the reduction of UK's dependence on gas imports, a combination of domestic and international policies (about exporters), could be useful.

Table1 provides researchers with some useful information about different aspects of the important reviewed models.

\section{((((Insert Table1 Here))))}

\section{Conclusion and suggestion for further research}

The role of system dynamics methodology on fossil fuel resources analysis has been improved from 1973. In these studies, system dynamics shows a significant role in dynamic modeling of fossil fuel resources. Referring to strengths and weaknesses as well as major policies suggested by previous studies as explained in Table 1, one can conclude that system dynamics approach can be considered for a variety of decision makings procedures and is capable of studying the causal dynamic relations between different sectors of energy systems, such as considerable delays in industry and new energy development, advanced varying technology, resource limitation and depletion, price fluctuation, increasing costs, growing demand, pollution and environmental concerns, political issues, etc.

System dynamics, which is an appropriate method for dynamic studies and policy analysis, has been used as one of the impressive methodologies in systemic research in this area. In this paper, not only the role of system dynamics in fossil fuel resources analysis has been illustrated, but also the main system dynamics models in this field were reviewed which could be a proper study guide for those who want to further research in this area.

There are some areas which necessitate further researches, including energy market structure and regulations, investment dynamics, risk assessment, technology development, sustainable development and energy-environmental issues.

\section{References}

Bassi, A. (2006). Modeling U.S. energy with threshold 21. In proceedings of the 24th international conference of the system dynamics society, 23-27 July 2006, Nijmegen.

Bodger, P. S., Hayes, D. J. and Baines, J. T. (1989). The dynamics of primary energy substitution. Technological Forecasting \& Social Change, Vol. 36, pp: 425-439.

Bodger, P. S. and May, D. G. (1992). A System Dynamics Energy Model of New Zealand. Technological Forecasting \& Social Change, Vol. 41, pp: 97- 106.

Budzik, P. M. and Naill, R. F. (1976). Fossill: a policy analysis model of the U.S. energy transition. Winter Simulation Conference, pp: 145 - 152.

Chi, K. C., Nuttall, W. J. and Reiner, D. M. (2009). Dynamics of the UK natural gas industry: System dynamics modeling and long-term energy policy analysis. Technological Forecasting \& Social Change, Vol. 76, Issue 3, pp. 339-357.

Choucri, N., Heye, C. and Lynch, M. (1990). Analyzing oil production in developing countires: a case study of Egypt. The Energy Journal, Vol 11, No 3, pp: 91-115.

Chowdhury, S. and Sahu, K. C. (1992). A System Dynamics Model for the Indian Oil and Gas Exploration/Exploitation Industry. Technological Forecasting \& Social Change, Vol. 42, pp: 63-83, doi:10.1016/j.techfore.2008.06.002.

Davidsen, P. I., Sterman, J. D. and Richardson, G. P. (1990). A Petroleum life cycle model for the U.S. with endogenous technology, exploration, recovery, and demand. System Dynamics Reveiw, Vol. 6, No. 1, pp: 66-93.

Fiddaman, T. S. (1997). Feeedback Complexity in Integrated Climate-Economy Models. Doctoral Thesis 
Submitted to the Alfred P. Sloan School of Management. Massachusetts Institute of Technology. Cambridge, MA 02139 .

Forrester, J. W. (1961). Industrial Dynamics. Pegasus Communications, 1st Ed., ISBN 1883823366.

Forrester. J. W. (1970). World Dynamics. Productivity Press, Portland, Oregon.

FOSSIL2: Energy Policy Model Documentation. (1980). Energy and Environmental Analysis, Inc. Department of Energy Contract No. AC01-79PE70143. Assistant Secretary for Policy, Planning and Analysis. Washington, D.C. 20585.

Ghali, K.H. and El-Sakka, M.I.T. (2004). Energy use and output growth in Canada: a multivariate cointegration analysis. Energy Economics, Vol. 26, Issue 2, pp. 225-238. doi:10.1016/S0140-9883(03)00056-2.

Hondroyiannis, G., Lolos, S. and Papapetrou, E. (2002). Energy consumption and economic growth: assessing the evidence from Greece. Energy Economics, Vol. 24, Issue 4, pp. 319-336. doi:10.1016/S0140-9883(02)00006-3.

Hubbert, M. K. (1956). Nuclear energy and the fossil fuels. Drilling and Production Practice, American Petroleum Institute \& Shell Development Co. Publication No. 95.

Hubbert, M. K. (1982). Techniques of prediction as applied to production of oil and gas. Oil and Gas Supply Modeling. Ed. S I Gass, National Bureau of Standards SP 631 (National Institute of Standards and Technology, Gaithersburg, MD), pp: $16-141$.

Jebaraj, S., Iniyan, S. (2006). A review of energy models. Renewable and Sustainable Energy Reviews, Vol. 10, pp. 281-311, doi:10.1016/j.rser.2004.09.004.

Lee, C.C. (2005). Energy consumption and GDP in developing countries: A cointegrated panel analysis. Energy Economics, Vol. 27, Issue 3, pp. 415-427. doi:10.1016/j.eneco.2005.03.003.

Lee, C.C. and Chang, C.P. (2005). Structural breaks, energy consumption, and economic growth revisited: Evidence from Taiwan. Energy Economics, Vol. 27, pp. 857-872. doi:10.1016/j.eneco.2005.08.003.

Lee, C.C. and Chang, C.P. (2008). Energy consumption and economic growth in Asian economies: A more comprehensive analysis using panel data. Resource and Energy Economics, Vol. 30, Issue 1, pp. 50-65. doi:10.1016/j.reseneeco.2007.03.003.

McIntyre, J. and Pradhan, M. (2003). A Systemic Approach to Addressing the Complexity of Energy Problems. Systemic Practice and Action Research, Vol. 16, No. 3, pp. 213-223.

Meadows, D.H., Meadows, D.L. and Randers, J. (1972). The Limits to Growth: A Report for the Club of Rome's Project on the Predicament of Mankind. Universe Books and Potomac Associates, New York.

Naill, R. F. (1973). The Discovery Life Cycle of a Finite Resource: a Case Study of U.S. Natural Gas. in: D.L. Meadows (Ed.), Toward Global Equilibrium: Collected Papers, MIT Press, Cambridge, MA.

Naill, R. F. (1976). COAL 1: A dynamic model for the analysis of United States energy policy. Hanover, N.H.:[s.n.].

Naill, R. F. (1977). Managing the Energy Transition: a System Dynamics Search for Alternatives to Oil and Gas. Ballinger Publishing Company, Cambridge, MA.

Naill, R.F., Belanger, S., Klinger, A. and Petersen, E. (1991). An analysis of the cost effectiveness of us energy policies to mitigate global warming. System Dynamics Review 8 (2), pp. 111-128.

Narayan, P.K. and Smyth, R. (2008). Energy consumption and real GDP in G7 countries: New evidence from panel cointegration with structural breaks. Energy Economics, Vol. 30, Issue 5, pp. 2331-2341. doi:10.1016/j.eneco.2007.10.006.

Oh, W. and Lee, K. (2004). Causal relationship between energy consumption and GDP revisited: the case of Korea 1970-1999. Energy Economics, Vol. 26, Issue 1, pp. 51-59. doi:10.1016/S0140-9883(03)00030-6.

Paula, S. and Bhattacharya, R.N. (2004). Causality between energy consumption and economic growth in India: a note on conflicting results. Energy Economics, Vol. 26, Issue 6, pp. 977-983. doi:10.1016/j.eneco.2004.07.002.

Sterman, J. D. (1980). The effect of energy depletion on economic growth. MIT online library.

Sterman, J. D. and Richardson, G. P. (1985). An Experiment to Evaluate Methods for Estimating Fossil Fuel Resources. Journal of forecasting, Vol. 4, pp: 197-226. doi:10.1002/for.3980040208.

Sterman, J. D., Richardson, G. P. and Davidsen, P. I. (1988). Modeling the Estimation of Petroleum Resources in 
the United States. Technological Forecasting \& Social Change, Vol. 33, pp: 219-249.

Sterman, J. D. (2000). Busyness Dynamics: systems thinking and modeling for a complex world. Irwin/McGraw-Hill, ISBN 0-07-231135-5.

Stern, D. I. (1993). Energy and economic growth in the USA: A multivariate approach. Energy Economics, Vol. 15, Issue 2, pp. 137-150. doi:10.1016/0140-9883(93)90033-N.

Stern, D. I. (2000). A multivariate cointegration analysis of the role of energy in the US macroeconomy. Energy Economics, Vol. 22, pp. 267-283.

System dynamic society. (2009). Retrieved from website: http:/www.systemdynamics.org/.

Radzicki, M. J. \& Taylor, R. A., Designer. (1997). Introduction to System Dynamics: A Systems Approach to Understanding Complex Policy Issues (Version 1.0). U.S. Department of Energy, Office of Policy and International Affairs, Retrieved, 2004, from: http://www.systemdynamics.org/DL-IntroSysDyn/inside.htm.

Tustin, E. (1953). The mechanism of economic systems. Harvard University Press, Cambridge, ASIN: B0000CIQPG.

World Energy Outlook. International Energy Agency (IEA), (2006).

World Oil Outlook. Organization of the Petroleum Exporting Countries (OPEC), (2008).

World Resources Institute. (2009). Retrieved from: http://www.wri.org/.

\section{Notes}

Note 1. More detailed information about the methodology could be found in Business Dynamics (Sterman, 2000) which is a useful, dominant reference in this field. 
Table 1. The review of fossil fuel resources system dynamics models

\begin{tabular}{|c|c|c|c|c|c|c|}
\hline हुํㄹㄹ & Gharacteristics & $\begin{array}{l}\text { Year } \\
\text { and } \\
\text { Country }\end{array}$ & $\begin{array}{l}\text { Fnergy } \\
\text { sources } \\
\text { studied }\end{array}$ & Main sectors of the model & Major scenarios and policies & weaknesses and strengths \\
\hline 1 & R. F. Naill & $\begin{array}{l}1973 \\
\text { United } \\
\text { States }\end{array}$ & Natural gas & $\begin{array}{l}\text { - Exploration } \\
\text { - Production } \\
\text { - Demand } \\
\text { - Investment }\end{array}$ & $\begin{array}{l}\text { - Unprover reserves } \\
\text { - Welthead price taxes } \\
\text { - Demand rate growth } \\
\text { - Investments } \\
\text { - Techuology factors } \\
\text { - Regabations }\end{array}$ & 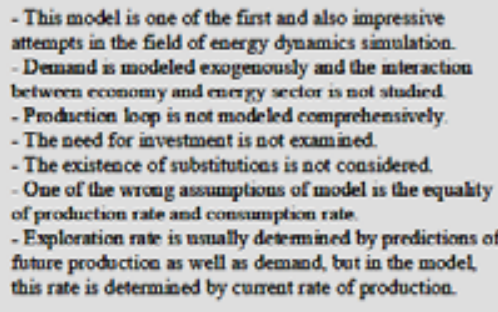 \\
\hline \multirow[t]{2}{*}{2} & \multirow{2}{*}{$\begin{array}{l}\text { J.D. Sterman } \\
\text { and } \\
\text { G. P. } \\
\text { Richurdson } \\
\text { and } \\
\text { P. I. Davidsen }\end{array}$} & $\begin{array}{l}1985 \\
\text { Wotld } \\
1988 \\
\text { United } \\
\text { States }\end{array}$ & Oil & $\begin{array}{l}\text { - Exploration and Discovery } \\
\text { - Production and Usage } \\
\text { - Technology } \\
\text { - Price, Revenue, and } \\
\text { lavestment } \\
\text { - Demand and Substitution }\end{array}$ & \multirow{2}{*}{$\begin{array}{l}\text { - Regulatice and price controls } \\
\text { - Tax } \\
\text { - Internal econcamic growth } \\
\text { - Exploratica and recovery } \\
\text { trechnology progress } \\
\text { - Costs } \\
\text { - The effect of substitution } \\
\text { - Supply policies of OPEC and } \\
\text { other soppliers } \\
\text { - Import costs and restrictions } \\
\text { - Reservation and strategic reserves }\end{array}$} & \multirow{2}{*}{$\begin{array}{l}\text { - The use of simulation and synthetic data approach } \\
\text { (Hubbert thesry of natural resources life cycle and } \\
\text { grologic analogy mediod) is cane of the model's } \\
\text { advantages } \\
\text { - These models resolve the mistakes of Naill's aatural } \\
\text { gas model over time. }\end{array}$} \\
\hline & & $\begin{array}{l}1990 \\
\text { United } \\
\text { States }\end{array}$ & Oil & $\begin{array}{l}\text { - Demand, lmport, and } \\
\text { Subotioution } \\
\text { - Envrstment } \\
\text { - Exploratica } \\
\text { - production } \\
\text { - Technology } \\
\text { - Revenue, Price, and Cost }\end{array}$ & & \\
\hline 3 & N. Cboucri & $\begin{array}{c}1990 \\
\text { Eipupt }\end{array}$ & Oil & $\begin{array}{l}\text { - Exploration (by } \\
\text { goverument and } \\
\text { mternaticnal onl companies) } \\
\text { - Production (by } \\
\text { gevernment and } \\
\text { internaticnal oul companies) } \\
\text { - Investment (by } \\
\text { povemment nnd } \\
\text { intemational oil companies) } \\
\text { - Internal Coosumption and } \\
\text { Export }\end{array}$ & $\begin{array}{l}\text { - Changes in intematicoal prices } \\
\text { - Clanges in dowestic prices } \\
\text { Changes in Rererves } \\
\text { - Chmings in private company's } \\
\text { share }\end{array}$ & 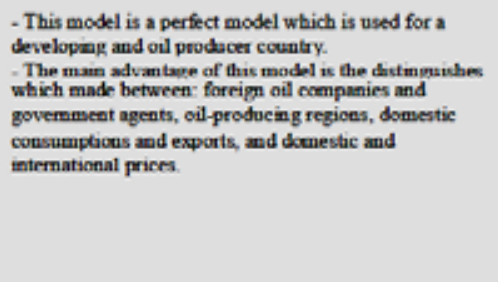 \\
\hline 4 & $\begin{array}{l}\text { S. Clowwdhury } \\
\text { and } \\
\text { K. C. Sahu }\end{array}$ & $\begin{array}{l}1992 \\
\text { Indua }\end{array}$ & Oil and gas & $\begin{array}{l}\text { Technical section } \\
\text { (Exploration / Explotatica) } \\
\text { - Financial section (lncome } \\
\text { Statement / Balance Stieet/ } \\
\text { Fund-Flow Statement) }\end{array}$ & $\begin{array}{l}\text { - Tax on Exploration } \\
\text { - Prodaction increase } \\
\text { - Future exploratice and } \\
\text { expleatation activities } \\
\text { - The masice of onl substitates mlo } \\
\text { the market } \\
\text { - Financial policies }\end{array}$ & 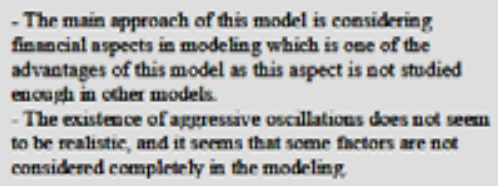 \\
\hline 5 & $\begin{array}{l}\text { P. S. Bodger } \\
\text { and } \\
\text { D. G. May }\end{array}$ & $\begin{array}{c}1992 \\
\text { Nealand } \\
\text { Zealed }\end{array}$ & $\begin{array}{l}\text { wood, eoal, } \\
\text { onl, gas, } \\
\text { mackear, and } \\
\text { sun }\end{array}$ & $\begin{array}{l}\text { - Evergy Rescarces } \\
\text { - Evergy Refimmg } \\
\text { lndustries } \\
\text { - Producer / Censumer } \\
\text { sectors of Society }\end{array}$ & $\begin{array}{l}\text { - The evaluation of alternative } \\
\text { energy sources }\end{array}$ & $\begin{array}{l}\text { - This model exnmines te dynamies of primary energy } \\
\text { swbstibaton a a noteworthy manner which provides } \\
\text { policy makers with usefiul insights to formulate national } \\
\text { policies. }\end{array}$ \\
\hline 6 & $\begin{array}{l}\text { K. C. Chi } \\
\text { and } \\
\text { w. J. Nutrall } \\
\text { and } \\
\text { D. M. Remer }\end{array}$ & $\begin{array}{c}2009 \\
\text { United } \\
\text { Kingdom }\end{array}$ & Natural gas & $\begin{array}{l}\text { - Exploration } \\
\text { - Production and } \\
\text { Consamiptisen } \\
\text { - Demand projection and } \\
\text { Substitution }\end{array}$ & $\begin{array}{l}\text { - Tax policies } \\
\text { - Demand } \\
\text { - Teehnology } \\
\text { - Independence level of gas import }\end{array}$ & $\begin{array}{l}\text { - This model basically is built co Sterman and } \\
\text { Richardson (1985) }\end{array}$ \\
\hline
\end{tabular}




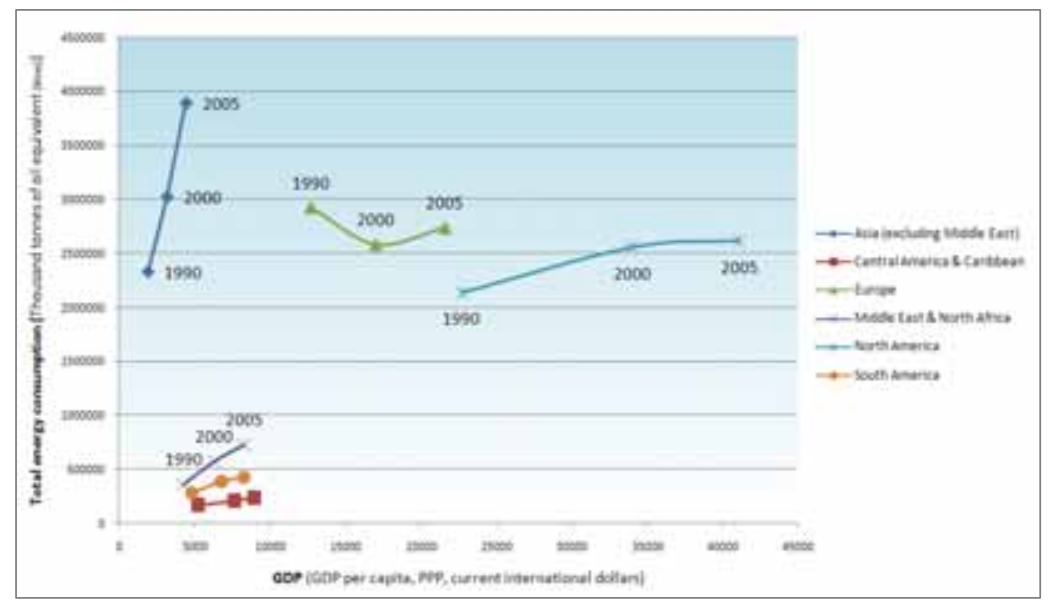

Figure 1. The relationship between energy consumption and GDP (Source: World Resources Institute)

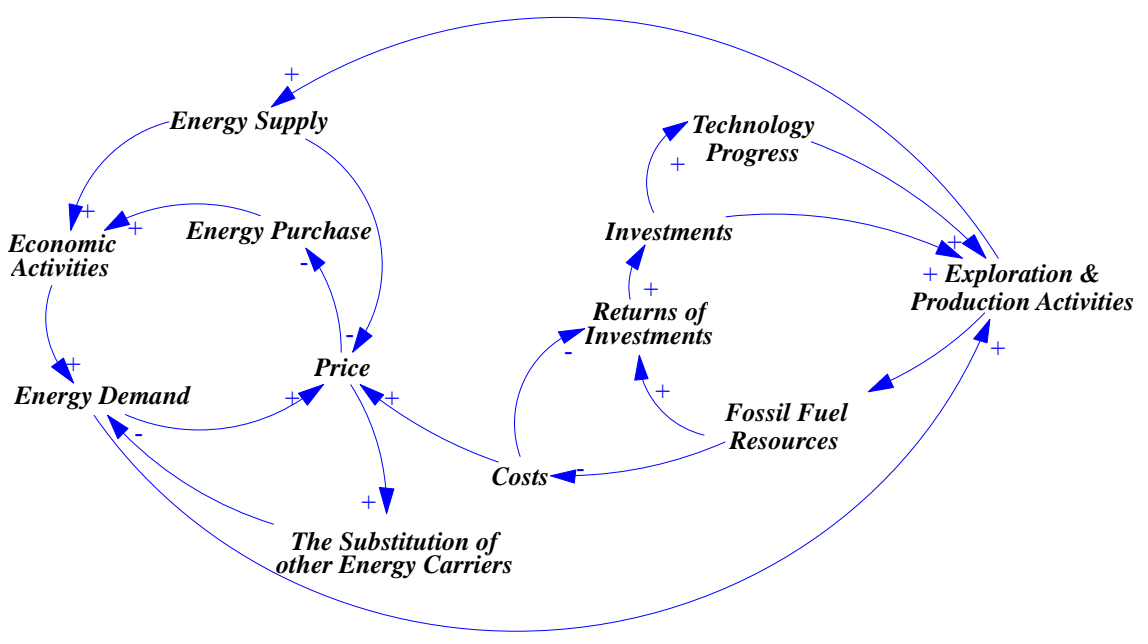

Figure 2. Dynamics of energy sector. 